
Journal of Indonesian Tourism and
Development Studies doi: 10.21776/ub.jitode.2019.07.02.03

E-ISSN : 2338-1647

http://jitode.ub.ac.id

\title{
Tourist Accomodation: A Host-Tourist Matched for Batur Geotourism
}

\author{
Ni Made Ernawati ${ }^{*}$ I Wayan Basi Arjana, Anak Agung Raka Sitawati \\ Department of Tourism, State Polytechnic Bali, Badung, Indonesia
}

\begin{abstract}
This article presents research results on tourist accommodation available in Batur geotourism: a host-tourist approach. It is developed based on a documentary study. There are four main studies on Batur conducted earlier which reports were assessed that are relevant to discover the match of tourist needs and the availability of tourist accommodation in Batur geotourism area. This qualitative research using secondary data which was conducted in an effort to find a solution to the issue of a short tourist stays in Batur. The assessment results show three matched types of accommodation that highly compatible between guest-accommodation available in Batur and tourists' needs for accommodation. These includes homestay covering basic and functional accommodation; moderate standard accommodation including the villa, guest house, and two/three-star hotel; and luxury accommodation inclusive tourist attractions comprising boutique hotel. This concludes that the short tourist stays in the area is not due to the unavailability of accommodation. Further assessment is required to discover the solution to the matter. The problems might lie on the lack of information and promotion or the limited tourist attractions and activities available in Batur; that require further action from the management of Batur tourism as well as the government of Bangli Regency to address the issue. It is expected that these study results could be used as a reference by Batur geotourism management to further develop the area.
\end{abstract}

Keywords: Accommodation, Community-based tourism, Geotourism, Geotourism products, Geotourists, tourist stays.

\section{Introduction}

A longer tourist stay improves the productivity of any tourist destination significantly. Even though, Batur geotourism site receives substantial number of visitors, at an approximate of 300 people per day, only a small number of tourists stay in Batur to explore and enjoy the place [1]. Further, the majority are dayvisitors who mostly came for the Sun-rise trekking. A question is raised: why not many tourists stay overnight in Batur? Related to the issue, some assumptions are postulated, which include: lack of the elements of to see and to do in Batur, as tourist attractions which play a very important part in extending tourist stay [2]. The other assumption is the lack of tourism facilities that support a longer tourist stay. In conjunction with the effort to extent tourist stay in Batur, this study was conducted to examine the types accommodation available in Batur and matches them with the needs of the visitors.

Batur is a geotourism site located in Bangli Regency in Bali Province in Indonesia. It is one of the most beautiful calderas in the world which was formed from the repeated eruptions of mount Batur [3]. Batur has a mild climate, at

\footnotetext{
*Correspondence Address:

Ni Made Ernawati

Email : madeernawati@pnb.ac.id

Address : State Polytechnic Bali, Uluwatu No. 45, Badung, Bali, 80361
}

$1717 \mathrm{~m}$ elevation, and the temperature could range $16-17^{\circ} \mathrm{C}[4]$; a warmer temperature is expected at the lower altitude around Batur caldera. Batur has many tourist attractions to offer starting from panoramic views around the caldera and atop the mountain; natural hot spring - a place to swim, culinaries, traditional lifestyle, geo-museum, temples and the lake (Fig. 1) [5].

Batur is registered as a member of the United Nation Global Geopark Network (UN-GGN) in 2012 [6]. UNESCO's Global Geopark Network scheme integrates conservation, education and the concept of sustainable and integrated development in a geological area embodied in geotourism. UNESCO defines geopark as a national conservation area that includes a number of vital, rare, or aesthetically pleasing geological heritage sites [7].

\section{Geotourism}

Geotourism includes the provision of services that enable tourists to have experiences not only for the purpose of appreciation and enjoyment but also for learning and understanding of the features of a geotourism-site. Dowling and Newsome particularly describe geotourism attractions which comprise: landscape, landforms, fossils, rocks, minerals, and an appreciation of the shaping and shaping process [8]. Meanwhile, Hose defines geotourism as providing facilities and interpretations along with 
(Ernawati, et al.)

other services that enable travelers to gain knowledge and understanding of the geology and geomorphology of a geotourism-site, which is not solely for the purpose of appreciating beauty [9]. The definition proposed by Hose encompasses all geotourism activities including the site management in order to provide facilities and services that enable visitors to enjoy the beauty of geological sites and promote appreciation for geology [9].

Geotourism is a part of Nature Tourism. Fennell [10] discussed the 'community conservation' model in which local people are actively involved in and benefit from the conservation project. The effort of conservation of a natural site should involve the people live around the place. This is because the local living depends on the immediate environment. Involving locals in tourism development will provide an economic opportunity for the locals an additional source of income; and other opportunities such as the expansion of sociocultural perspectives, increasing the locals' awareness and ability to participate in nature conservations. Community's involvement in any stage of tourism development and operation is referred to community-based tourism, wherein the locals manage and provide tourism services such as accommodation, tourist guide, local and traditional dishes, and transportation.

\section{Accommodation for Geotourism}

Tourism products could be divided into two main categories: attractions and industry elements [11]. The industry elements include travel services, accommodation, food and beverage services, transportation, souvenir. While, Frochot and Bata [12] argued that tourism product is tourist's experiences; thus, tourist satisfaction depends on all elements that composed the products.
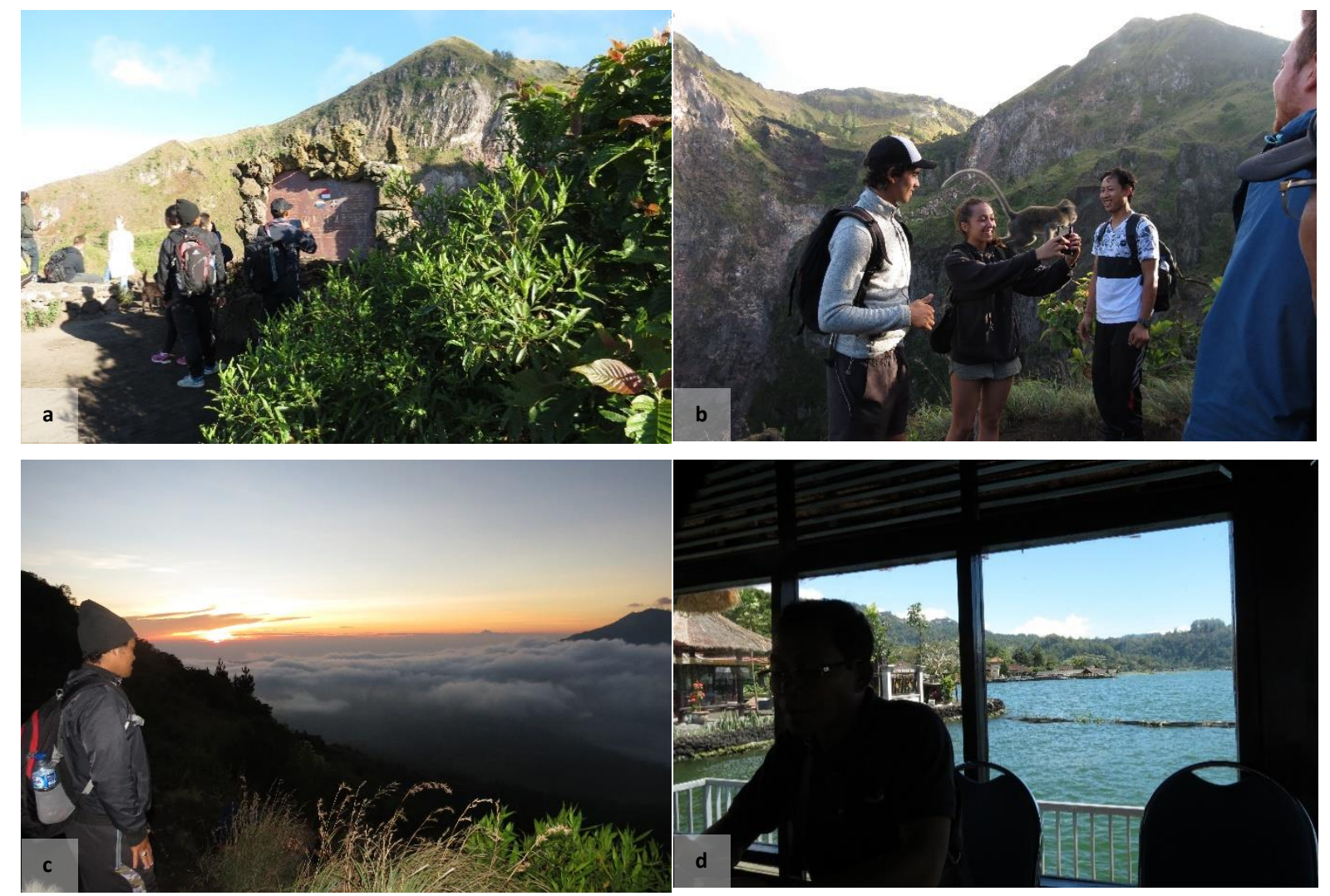

Figure 1. Batur Geotourism Site [5]

Description: a) top of Mount Batur - trecking terminating point, b) tourist interacted with local fauna, c) sunrise at the top of Mount Batur, d) restourant with lake view. 
Within the entire range of accommodation from luxurious to budget, accommodation are differentiated into two main types, which include: serviced and self-catered [13]. Community-based tourism (CBT) tourists' needs on accommodation and identify three types of accommodation which include [14]:

1) good standard accommodation, such as villastyle accommodation in the village

2) homestays - clean rooms in villages with basic facilities for budget travelers that enable close interaction with hosts

3) luxury accommodation in resorts for day trippers.

Further, projecting age and accommodation types, more mature visitors prefer to access CBT products on day trips from their resort hotels, or stayed overnight in villas in the village. Younger travelers, who commonly travel on a budget, prefer homestays and intermingle with local people, provide they have clean facilities and a comfortable bed [14].

AA Hotel Services [15] assessed the standard quality of hotel services from 13 aspects, which are divided into 2 categories, namely:

\section{1) Value for consumers}

a. Intrinsic quality - the intrinsic value of accommodation: 'an overnight service'.

b. Condition - care and appearance of items: Is there a function suitability?

c. Physical and personal comfort - does quality support user's comfort?

d. Attention to detail - proof that attention and service have been given and done to ensure the customer experience is special, and a high standard for all.

e. Guests' choice and ease of use - customer experience is enhanced by providing choices such as choices in the room type and menu selection. This can be improved by exploring how useful and efficient the substaces for customers.

f. Presentation - the way room and its content are displayed both on arrivalduring stay.

2). Standard assessment of lodging services

a. Overall standards (General standards)

b. Services

c. Meals/Breakfast - Dining quality and information (food quality and during dining)

d. Bedrooms

e. En-Suite bathroom and shower rooms or private facilities f. Public areas

g. External areas (Areas outside the hotel)

Accommodation as one element of the tourist products plays very important part in delivering quality tourist experience. The availability of accommodation enables tourists to extent their stay thus increases the income of the destination. One of the way for local community participating in tourism is by providing accommodation for tourists. Thus, tourist spending goes directly to the local community members. Since, capital is a common limitation of community's participation in tourism [16], the accommodation offered by locals could be as simple as a spare room in a share building. Nonetheless, safety and cleanliness are requirements in running a homestay, wherein guest accommodation should be professionally provided and handled.

\section{Geotourist}

Geotourist is a niche within the alternative tourist markets. This segment is featured by particular interests and specific needs. Generally, alternative tourists travel alone or in a small group and participate in different challenges [17], enjoy and appreciate interaction with the local community members [18], consume local culinary [19], and enjoy cultural diversity as an instrument of self-enrichment [20]. They want to experience something different from their everyday lives, and are interested in ethnic culture, rural environment and natural beauty [21]. Alternative tourists usually accept the basic facilities available in villages [22], and want to contribute to the local community [20]. A previous study conducted on community-based tourism and identified two types of CBT tourists, day trippers and overnighters. Both types presented similar characteristics with the overnighters interested in a more engaged CBT experience [14].

The Travel Industry Association of America (TIAA) identified 16.3 million (29.6\%) tourists as Geo-savvy whose profiles are: young people, highly educated, and environmentally conscious [23]. Mamoon conducted a study and discovered that the motivation of geotourists is primarily rooted in a person, thus the activity is valuable for the traveler her/himself [24]. Further, the author classifies five main intrinsic motivations of geotourists which include: to take a rest from the chaotic daily activities, to relax, to enjoy geotourism sites, to feel adventurous, and to advance knowledge. 
Knowing customer needs is vital for geotourism managers. In several failure cases of tourism developments including $\mathrm{CBT}$, the problem is rooted from the unidentified target market [16]. Thus, it is important for marketers and developers of tourism sites to understand their market segments. The failure in identifying the target market disables the developers to identify needs of the prospective customers, thus unable to focus in fulfilling these needs. These needs include the provision of accommodation services. To match the prospective customers' need, it is vital for local community members who participate in providing services especially visitors' accommodation to understand the target market of the respective destination or the tourist site.

\section{METHODOLOGY}

This articles was developed based on a qualitative documentary study using secondary data. The study includes assessing reports of the earlier studies conducted mainly by the authors and supplemented by a literature review. There are four studies that had been conducted earlier. The first research is in regard to products of community-based tourism - a case study in Bali. The next is a study specifically on geotourism products a tourist perspective in Batur. This was followed by an assessment on geotourism products that could be provided by the local community members in Batur, a local perspective. The last study is in regard to the accommodation available in Batur.

The study reports were examined and the information was divided into 2 classifications: accommodation from the 'supply perspective' and 'tourist perspective'. Lastly, both sections of information were compared to discover the match between the demand and the availability.

\section{RESULTS AND DISCUSSION \\ Tourist Accommodation in Batur}

The results of the earlier study on CBT tourists' needs for accommodation identified three types of accommodation, which include: homestay and villa in the village, and luxurious accommodation in tourist resorts [14]. It also found that some tourists who came for a day visit to a CBT village stayed in resort hotels.

The results of the first study conducted specifically in Batur regarding the general aspect of products including accommodation from tourist perspective indicated that the tourists' desire on accommodation ranging from budget to luxury accommodation [1]. It is generally expressed that cleanliness is a prime important in all aspect of tourism facilities, this to include clean bed room from dust and free of stuffy odour. Further, this study identified three types of accommodation: homestays, villas and luxurious accommodation which represent the needs of the variety of market segments. An opinion also expressed that a luxury accommodation in wilderness i.e. in Batur is an attraction for tourists. This study also discovered that most of the tourists visiting Batur is in pursue of the Sun-rise climbing. The climbers will go straight back to their base which is outside Batur after the climbing is completed, thus no accommodation is needed in Batur; only the minority of respondents stay overnight in Batur. Most of the respondents do not know if accommodations are available in Batur.

In the second study [25] on accommodation from the 'supply-side' examined the type and standard quality of accommodation available in Batur based on the 13 aspects of standard set by AA Hotel Services [15], plus one aspect of 'cleanliness'; thus, made up a total of 14 aspects. This study identified four types of accommodation available in Batur, these include: Homestay - a basic and functional accommodation, Villa/Guest-house, Hotel of two/three star, and Boutique hotel; the descriptions are provided in the following section.

Homestay is the accommodation offered by locals who have spare room/s to be rented for tourists (Fig. 2). This type of accommodation is usually very basic and only fulfills minimal functions of a lodging, which are usually managed amateurly either in the aspects of services, physical buildings, style and arrangement of rooms and the home yards.

Villa is a special building that is specifically dedicated to providing accommodation for tourists which is usually delivered in a good standard (Fig. 3 - 4). However, in some cases this type of property is managed with less professionalism due to lack of ability of the staff or amateur management. Two-three-star hotel is an accommodation property that has reasonably large number of rooms with 2-3-star service standard (Fig. 5). 

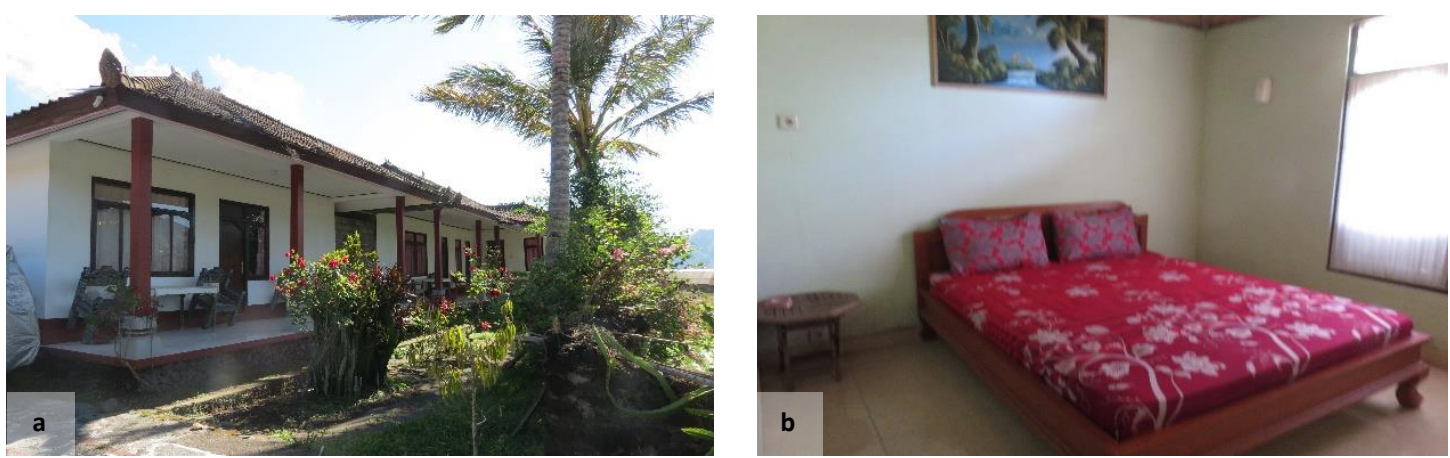

Figure 2. Homestay

Description: a) homestay front view, b) standard bed in homestay (Personal documentation, 2018)
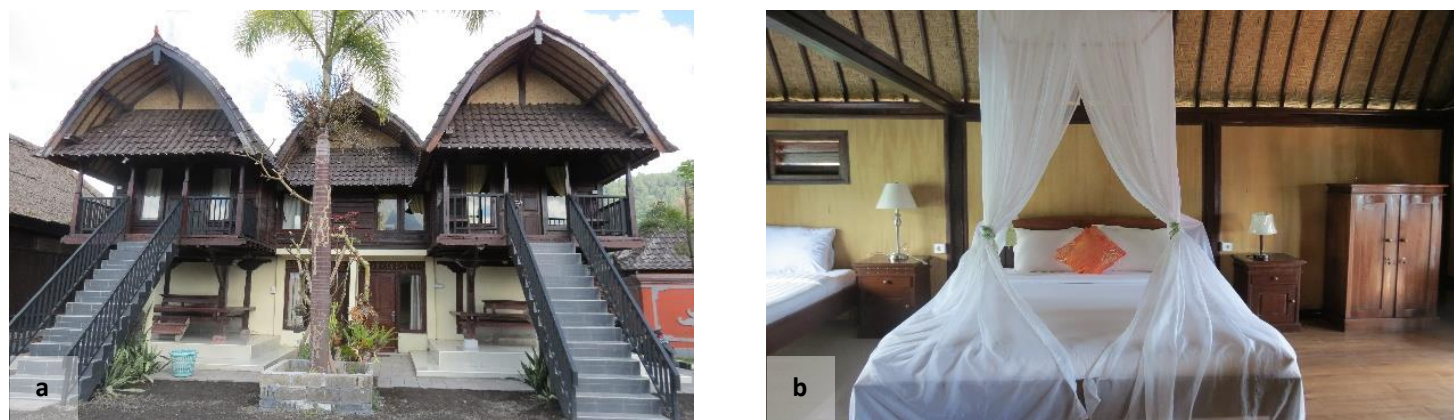

Figure 3. Villa - Traditional style

Description: a) villa front view, b) standard bed in a traditional villa (Personal documentation, 2018)
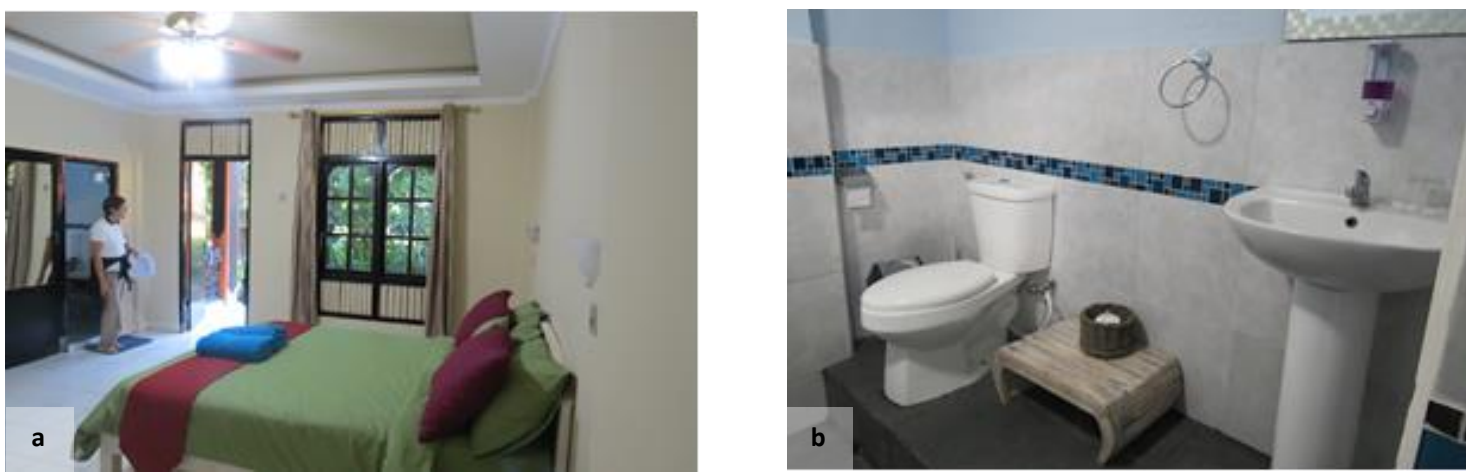

Figure 4. Villa - Contemporary style

Description: a) standard bed in a contemporary villa, b) standard bathroom in a contemporary villa (Personal documentation,

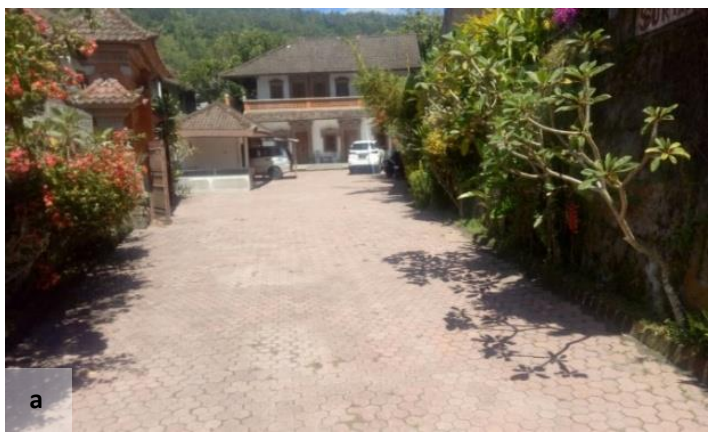
2018)

Figure 5. Two/three-star hotel

Description: a) hotel front view, b) standard bed in a two/three-star hotel (Personal documentation, 2018) 

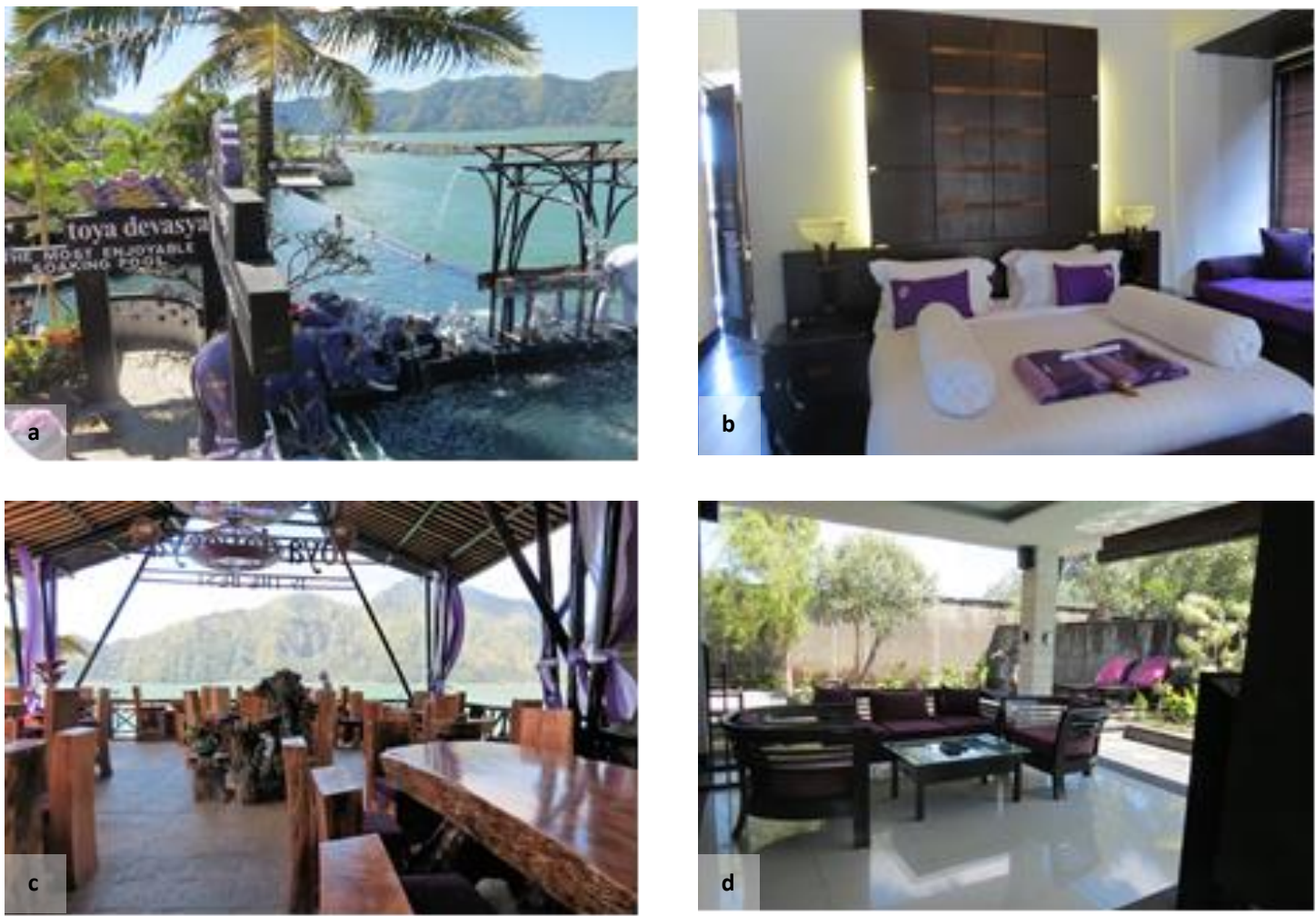

Figure 6. Boutique Hotel in Batur

Description: a) soaking/swimming pool, b) standard bed in a boutique hotel, c) dining room, d) lounge (Personal documentation, 2018)

Boutique hotel is a small scale property that offers luxury accommodation that has a special feature which becomes an attraction for guests [26]. There is one business that offers such service in Batur Geotourism with a variation of room types which include: suit room for honeymooners, family and the standard superior rooms (Fig. 6). This boutique hotel which is located in one side of Batur lake highlights its attractions with various type of swimming pools. The hotel has more than four swimming pools using room temperature and warm water with spectacular blended to nature pool design that unites the pool and the lake which gives an ambiance that the guests are swimming in Batur lake.

\section{Tourist Accommodation in Batur: A Supply- Demand Match}

Assessing the accommodation available in Batur and the tourist needs, it seems that they are highly matched. Even though it appears that the supply side indicates the availability of 4 accommodation types and the tourist's needs are classified into 3 (Fig. 7). As the two/three-star hotel could be classified into middle standard accommodation similar to villa or guest house, noting that this type of property has more rooms to offer.

Between the availability and the need for accommodation in Batur geotourist, seemingly, there are differences namely: 4 classifications on the 'Availability' side and 3 classifications on the 'Need' side. However, basically both sides refer to the same essence, namely:

1) Budget accommodation to meet the basic need for the overnighters prioritising cleanliness, which leads to the 'homestay' type of accommodation.

2) Quality accommodation to meet the basic function as well as to fulfill the need of personal comfort, and aesthetic value which leads to villas, guest houses and two/threestar hotels.

However, selecting this type of accommodation requires caution during purcahase and product survey, as there are properties despite of being classified into this category, nonetheless offer less adequate quality in terms of basic function, comfort and aesthetic.

3) Luxury accommodation which also functions as tourist attractions. 
There is one provider that meets this category, which is classified as boutique hotel. The business has a few luxurious suit rooms with a 'private pool'. This place is a paradise for those who enjoy swimming, there are warm and room temperature pools with various ambiance. A pool located on the edge of the lake applies a design as if guests are swimming in Lake Batur. Therefore, the property offers accommodation and entertainment.

In response to the question: why not many guests stay overnight in Batur? It could be identified now, it is not due of the unavailability of accommodation or a particular standard of hotel required by visitors. It is supported by the expression of one research participant stated that after the Sunrise trekking, she will go directly to Denpasar and have lunch on the way [1]. It is further stated that she did not know if there is anything they could do in Batur other than the Sunrise climbing. From this expression, it seems that the reason for a short tourist stay might be caused by the unavailability of sufficient elements of to see and to do by visitors (tourist activities). The other possibility could be the lack of information on tourist attraction in Batur, thus information of all attractions within the whole Batur area needs to be made available. This will give choices to the tourists and an idea on how they will spend their time in Batur. Nonetheless, these hypotheses need to be further examined in search for the solution to the short tourist stay.

\section{CONCLUSION}

Based on quality and types, there is high compatibility between the supply of accommodation and the tourist's needs of accommodation in Batur. The supply-demand match of accommodation in Batur is within three domains, these include: homestay - basic and functional accommodation; villa, guest house, and two/three-star hotel; and boutique hotel.

It could be concluded that the short tourist stay in the site is not caused by the unavailability of accommodation or a particular standard of accommodation required by the tourists. The problems might be triggered by the lack of communication, promotion or the limitation of tourist attractions and activities in Batur. In this case, the need for accommodation needs to be created.

\begin{tabular}{|c|c|}
\hline \multicolumn{2}{|c|}{ Tourist accommodation in Batur: A supply-demand match } \\
\hline $\begin{array}{c}\text { Accommodation available in } \\
\text { Batur Geotourism }\end{array}$ & $\begin{array}{l}\text { Tourist's needs of Accommodation } \\
\text { in Batur }\end{array}$ \\
\hline $\begin{array}{l}\text { 1. Homestay - only serve basic } \\
\text { functions - a place to spend } \\
\text { the night and rest } \\
\text { 2. Villa/Guest house - a good } \\
\text { quality lodging, sometimes } \\
\text { has accommodated aesthetic } \\
\text { elements } \\
\text { 3. 2-3-star hotel } \\
\text { 4. Boutique hotel }\end{array}$ & $\begin{array}{l}\text { 1. Homestay - the need for basic } \\
\text { lodging facilities for 'budget } \\
\text { travelers } \\
\text { 2. Villas are quality accommodations } \\
\text { that have integrated the elements } \\
\text { of comfort and aesthetics into } \\
\text { their product design } \\
\text { 3. The need for a luxury } \\
\text { accommodation is expressed by } \\
\text { respondent which is not solely to } \\
\text { meet the need for high standard } \\
\text { accommodation; a luxury } \\
\text { accommodation in the wild is } \\
\text { regarded as tourist attraction. }\end{array}$ \\
\hline \multicolumn{2}{|c|}{$\begin{array}{l}\text { Accommodation in Batur geotourism: a supply and demand match: } \\
\text { 1. Budget accommodation - homestay, basic and functional accommodation } \\
\text { 2. Moderate standard accommodation - villa, guest house, and two/three-star hotel } \\
\text { 3. Luxury accommodation - boutique hotel. }\end{array}$} \\
\hline
\end{tabular}

Figure 7. Tourist Accommodation in Batur: A Supply-Demand Match 
These actions are required in larger scale covering a wider scope. The management of Batur tourism as well as the government of Bangli Regency could play a very important role and provide assistance in addressing the emerging issue. This for example, prommotion could be conducted efectively for Batur holistically as a tourist site rather than individual busines/accommodation, which introduce all supporting facilities and tourist attractions available. Batur could strengthen its existing tourist attraction and by developing more variety of attractions, for instance: developing Batur lake as attraction focal point, and the traditional culture - a unique Batur farming life syle to support the nature base tourist attraction - the current geotourism attractions.

Nonetheless, further assessment is required to precisely identify the problem and solve the issue; therefore, the tourist-stay could be extended and subsequemtly an increase earning form tourism. These study results acade-mically could add a reference on accommodation studies especially for Geotourism. Practically, it can be used as a reference by tourism stakeholders, particularly, Batur Geotourism Manage-ment and the local government of Bangli Regency to further develop the area.

\section{REFERENCES}

[1] Arjana, I W. B., N. M. Ernawati and I K. Astawa. 2017. Geotourism products industry element: A community approach. IOP Conf. Series: Journal of Physics: Conf. Series 953 (2017) $012106 . \quad$ DOI :10.1088/1742-6596/953/1/012106

[2] Ernawati, N. M. 2015. Producer-market orientation of community-based tourism (CBT) products: A case study in Bali, Indonesia. Unpublished thesis. Edith Cowan University. Perth, Australia.

[3] Dowling, R. 2014. Batur Global Geopark. Edith Cowan University. Perth, Australia.

[4] Mountain - Forest.com. 2018. Weather forecast, Indonesia. Available at: https://www.mountainforecast.com/peaks/Batur/forecasts/1717.

[5] Ernawati, N. M., A. A. R. Sitawati and N. K. Muliati. 2018. Batur toward sustainable tourism development - a community-based geotourism case from Bali in Indonesia. Journal of Environmental Management and Tourism 2(26), 291297. DOI: 10.14505/ jemt.v9.2(26).09.
[6] Igan, S., I. S. Sutawidjaja, O. Abdurahman, T. Bachtiar, and A. Kurnia. 2012. Taman Bumi Pertama Kaldera Batur (Batur Caldera the First Geopark). Geomagz, 19-37.

[7] UNESCO. 2006. Global Geoparks Network. Available at: http://portal.unesco.org/ science/en/ev.php.

[8] Dowling, R. and D. Newsome. 2006. Geotourism. Elsevier Butterworth-Heinemann. Oxford.

[9] Hose, T. 2008. Towards a history of geotourism: definitions, antecedents and the future. In: Burek, C. and C. Prosser, (Eds). The History of Geoconservation. Geological Society. Bath.

[10] Fennell, D. A. 2015. Ecotourism. Routledge. London, UK.

[11] Weaver, D. and L. Lawton. 2010. Tourism Management. John Wiley and Son. Milton, Australia.

[12] Frochot, I. and W. Bata. 2013. Marketing and designing the tourists experience. Goodfellow Publisher Limited. Oxford, UK.

[13] Holloway, J. C., C. Humphreys. 2012. The business of tourism. Pearson. Essex, UK.

[14] Ernawati, N. M., R. Dowling and D. Sanders. 2015. Tourists' perceptions of community based tourist products for sustainable tourism in Bali, Indonesia. In: Hughes, M., C. Pforr and D. Weaver (Eds). The Practice of Sustainable Tourism. Routledge. London, UK. 95-112.

[15] AA Hotel Services. 2006. AA Quality standards for hotels - visit Britain. AA Hotel Services. London.

[16] Telfer, D. J. and R. Sharpley. 2008. Tourism and development in the developing world. Routledge. New York, USA.

[17] Scheyvens, R. 2002. Tourism for development empowering communities. Pearson Education limited. Singapore.

[18] Weaver, D. 2006. Sustainable tourism theory and practice. Elsevier. Oxford, UK.

[19] Fiorello A. and D. Bo. 2012 Communitybased ecotourism to meet the new tourist's expectations: An exploratory study. Journal of Hospitality Marketing and Management 21, 748-778. DOI: 10.1080/19368623. 2012.624293.

[20] Lpez-Guzman, T., O. Borges and A. M. Castillo-Cnalejo. 2011. Community-based tourism in Cape Verde - case study. 
Tourism and Hospitality Management 17(1), 34-44. UDC.338.486.(665.823).

[21] Goodall, B. 1995. Environmental auditing: A tool for assessing the environmental performance of tourism firms. The Geographical Journal 161(1), 21-28.

[22] Boo, E. 1991. Making ecotourism sustainable: Recommendations for planning, development, and management. In: Whelan, T. (Ed). Nature Tourism: Managing for the Environment Island Press. Washington, US. 187-199.

[23] National Geographic. 2002. Center for sustainable destination. Available at: http://www.nationalgeographic.com/travel /sustainable/ about_geotourism.html.

[24] Mamoon, A. 2011. Toward a better understanding of motivations for a geotourism experience: a selfdetermination theory perspective. Edith Cowan University. Perth, Australia.

[25] Ernawati, N. M., I W. B. Arjana, N. M. Sudarmini. 2018. Jasa penginapan pendukung geowisata di Batur Bali. Proceeding of National Seminar on Innovative Applied Research. State Polytechnic Bali. 23-24 August 2018.

[26] Xotels Ltd. 2018. Boutique Hotel. Available at: https://www.xotels.com/en/glossary/ boutique-hotel. 